\title{
RESULTS OF THE STUDY OF FILMS OBTAINED BY ADDING VARIOUS IMPURITIES TO THE SOLUTION OF NICKEL PHOSPHIDE
}

\author{
P. Abdurazova, Sh. Koshkarbayeva, M. Sataev, N. Dzhakipbekova \\ and Y. Raiymbekov" \\ Department of Chemical Technology of Inorganic Substances, M.Auezov South Kazakhstan \\ State University, Shymkent, Kazakhstan \\ *E-mail : eplusr@bk.ru
}

\begin{abstract}
The article presents the results of research on the production of chemical films of nickel phosphide with the addition of some impurities such as ferrophosphorus and carborundum. Magnetic stirrer and purge method were used for research. As a result of the study, when analyzing the quality and composition of the obtained films, it was found that the quality of the films obtained by purging is high. With the help of scanning electron microscopy, the quality of the obtained film was analyzed, the elemental composition was determined.

Keywords: Chemical Films, Nickel Phosphide, Chemical Method, Solution, Metal.
\end{abstract}

(C) RASĀYAN. All rights reserved

\section{INTRODUCTION}

As a result of corrosion and premature physical deterioration of metal products, a significant part of the metal produced in the world $(5-10 \%)$ is used inefficiently. This leads to high costs. In this regard, one of the main goals is to save metal and protect it from premature physical damage. The most effective way to protect metals from corrosion is to obtain modified coatings by incorporating various powders into its composition. $^{1-3}$

A distinctive feature of chemical coatings is that such coatings have a high corrosion resistance compared to others, a low coefficient of friction and a smooth, high gloss. Composite coatings combine aesthetic, electro-heat-conducting and heating properties of metals, increased hardness. ${ }^{4-6}$

Composite coatings, which include various mixtures, allow combining the properties of areas of substances with electroplating and the properties of other materials, to improve the surface properties. Upon receipt of composite coatings such as graphite-copper, carborund-copper increases electrical conductivity, resistance to friction, does not oxidize when interacting with oxygen in the air, chemically attaches to all aggressive aqueous solutions compared to precious metals, and reduces the coefficient of friction. $^{7-9}$

The main objective of the study is to obtain a coating of modified nickel phosphide with high wear resistance and low friction coefficient by incorporating into the composition of nickel phosphide a Ferro phosphoric powder, which is an auxiliary product of production.

\section{EXPERIMENITAL}

To obtain a high-quality coating, it is necessary to carry out a complete treatment of the sample surfaces. The surface of the uneven model is mechanically cleaned and leveled. To align with the surface of the samples, oxide scales and other roughness, the surface of the template is cleaned with emery paper.

After mechanical cleaning, the process of removing fats from surface areas occurs using chemical solutions of the sample surfaces. The composition of the degreasing solution in research work $(\mathrm{g} / \mathrm{L})$ : $\mathrm{NaOH}-20-40 \mathrm{~g} / \mathrm{L} ; \mathrm{Na}_{2} \mathrm{CO}_{3}-20-40 \mathrm{~g} / \mathrm{L} ; \mathrm{t}^{\circ}=60-70^{\circ} \mathrm{C}$, degreasing time -6 minutes.

Rasayan J. Chem., 13(1), 346-353(2020)

http://dx.doi.org/10.31788/RJC.2020.1315539

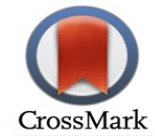


RASĀYAN J. Chem.

Vol. 13 | No. 1 |346 - 353| January - March | 2020

Subsequently, the process of removing degreased samples is performed by dissolving corrosion products and oxide shells from the surface of products in acidic solutions. As the temperature rises, the rate of rust removal increases. The composition of the processing solution $(\mathrm{g} / \mathrm{l}): \mathrm{H}_{2} \mathrm{SO}_{4}-100 \mathrm{~g} / \mathrm{L} ; \mathrm{t}^{\circ}=18-25^{\circ} \mathrm{C}$. The treatment is carried out for 1 to 2 minutes by immersing the product in a special glass container. A scanning electron microscope with the JSM-6490 LV system was used to study the microstructure of the samples.

\section{RESULTS AND DISCUSSION}

According to the results of the research, it was established that the quality of the nickel coating obtained as a result of the experiment carried out with air blowing will result in a smooth, high-gloss package compared to the quality of the sludge obtained on a hot plate with a special mixing device.

Therefore, the following studies were carried out by mixing the solution with air. First of all, the composition of the powder of ferrophosphorus used for research was determined in a scanning electron microscope; the result obtained is shown in Table-1 and Fig.-1.

Table-1: Elemental Composition

\begin{tabular}{c|c|c}
\hline Element & Weight, $\%$ & Atomic, $\%$ \\
\hline $\mathrm{C}$ & 5.90 & 18.03 \\
\hline $\mathrm{O}$ & 5.37 & 12.32 \\
\hline $\mathrm{Na}$ & 0.83 & 1.33 \\
\hline $\mathrm{Mg}$ & 0.12 & 0.18 \\
\hline $\mathrm{Al}$ & 0.16 & 0.22 \\
\hline $\mathrm{Si}$ & 1.79 & 2.34 \\
\hline $\mathrm{P}$ & 17.20 & 20.38 \\
\hline $\mathrm{S}$ & 0.56 & 0.64 \\
\hline $\mathrm{Cl}$ & 0.63 & 0.66 \\
\hline $\mathrm{K}$ & 0.11 & 0.11 \\
\hline $\mathrm{Ca}$ & 0.51 & 0.47 \\
\hline $\mathrm{Ti}$ & 0.79 & 0.61 \\
\hline $\mathrm{Cr}$ & 0.36 & 0.25 \\
\hline $\mathrm{Mn}$ & 1.88 & 1.26 \\
\hline $\mathrm{Fe}$ & 60.07 & 39.49 \\
\hline $\mathrm{Cu}$ & 2.64 & 1.52 \\
\hline $\mathrm{Pb}$ & 1.07 & 0.19 \\
\hline
\end{tabular}
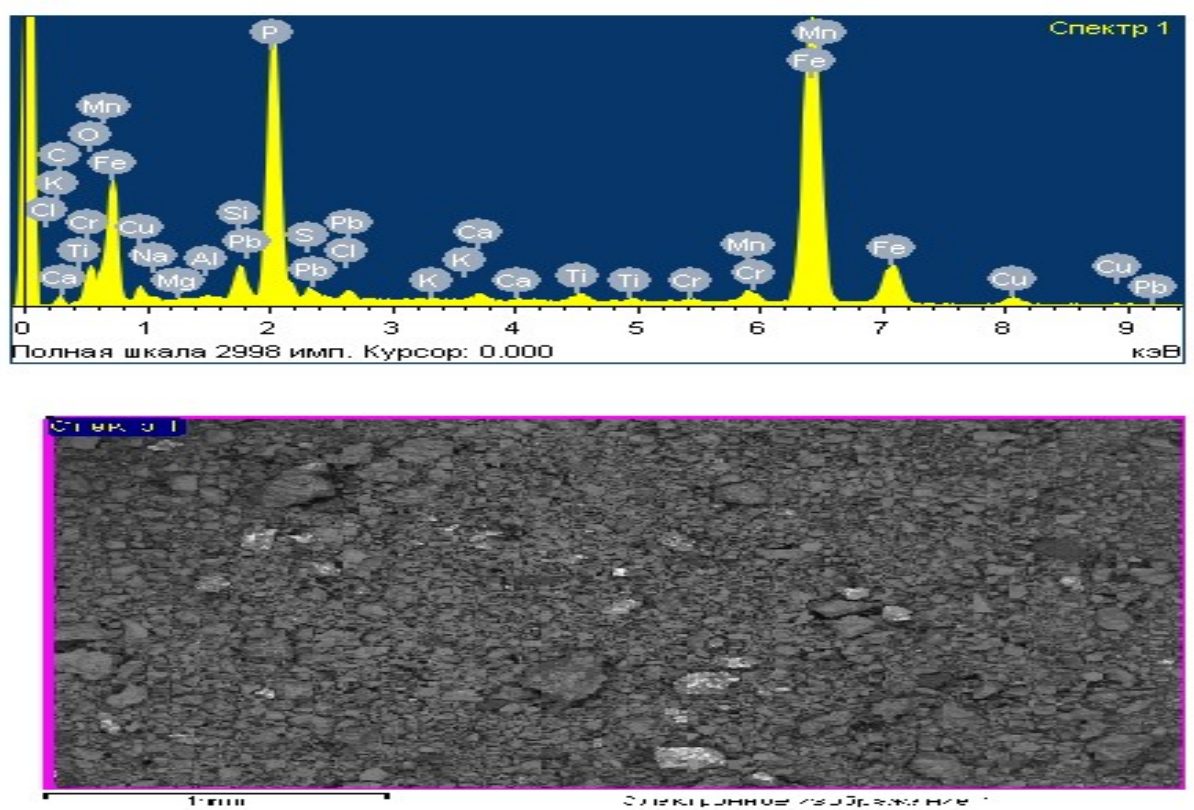

Fig.-1: Structural Composition of Ferrophosphorus Powder 
RASĀYAN J. Chem.

Vol. 13 | No. 1 |346 - 353| January - March | 2020

According to the data obtained as a result of the study, it was established that ferrophosphorus by mass fraction is $\mathrm{P}-17.20, \mathrm{Fe}-60.07$. Other elements, such as titanium, chromium, and manganese, lead contained in the powder, do not reduce the quality of the coatings.

In order to study the quality of the coating, which included the powder of ferrophosphorus, studies were conducted on acidic electrolytes of different composition. The following solutions were selected as acid electrolytes:

The composition of the solution No. 1, g/L:

1. $\mathrm{NiSO}_{4} \cdot 7 \mathrm{H}_{2} \mathrm{O}-30$

2. $\mathrm{NaH}_{2} \mathrm{PO}_{2}-10$

3. $\mathrm{CH}_{3} \mathrm{COONa}-10$

$\mathrm{T}-80-90^{\circ} \mathrm{C}$

pH 4.5-5.

The composition of the solution No. 2, g/L:

1. $\mathrm{NiCI}_{2}-30$

2. $\mathrm{NaH}_{2} \mathrm{PO}_{2}-10$

3. $\mathrm{CH}_{3} \mathrm{COONa}-10$

$\mathrm{T}-80-90^{\circ} \mathrm{C}$

$\mathrm{pH}$ 4.5-5.

The composition of the solution No. 3, g/L:

1. $\mathrm{NiSO}_{4} \cdot 7 \mathrm{H}_{2} \mathrm{O}-20$

2. $\mathrm{NaH}_{2} \mathrm{PO}_{2}-20$

3. Succinic acid -10

$\mathrm{T}-80-90^{\circ} \mathrm{C}$

$\mathrm{pH}$ 4.5-5.

In each electrolyte, studies on obtaining a nickel phosphide precipitate were carried out for 5 hours. When conducting a study from the obtained data was found the thickness of the package. From solutions taken coating of steel materials with a smooth surface. The results are shown in Table-2 and Fig.-2.

Table-2: Thickness of Coatings Obtained From the Composition of Various Solutions

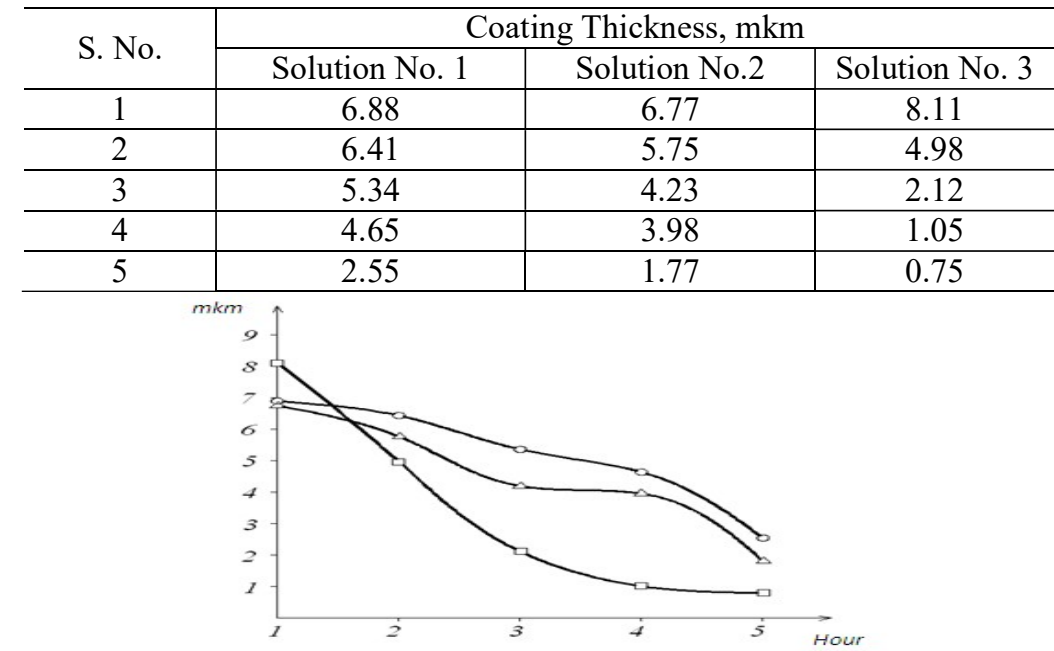

$$
\text { - Solution curve No. } 1 ; \quad \square \text { - Solution curve No. } 2 ; \Delta \text { - Solution }
$$

Fig.-2: The Dependence of the Thickness of the Package on the Time Obtained From the Composition of Different Solutions 
RASĀYAN J. Chem.

Vol. 13 | No. 1 |346 - 353| January - March | 2020

When laying the coated sample into the solution, it is first of all shown that the deposition rate of nickel is high at first, but the deposition rate decreases with time.

Solution No. 1 was chosen for research, since the deposition rate of the coating from solution No. 3 is high and from solution No. 2 is low. The rate of deposition of the solution No. 1 compared with solutions No. 2, No. 3 medium. Therefore, solution No. 1 was used for other studies.

The effect of the concentration of sodium hypophosphite, which is the main component in the selected solution, on the nickel phosphide deposition rate was also studied. The solution prepared according to the different composition of sodium hypophosphite is shown in Table-3.

Table-3: Solution prepared according to the Different Composition of Sodium Hypophosphite

\begin{tabular}{c|c|c|c}
\hline \multirow{2}{*}{ Components } & \multicolumn{3}{|c}{ The Concentration of Components in Solution, g/L } \\
\cline { 2 - 4 } & \multicolumn{3}{|c}{$\mathrm{pH} \mathrm{5-6}$} \\
\cline { 2 - 4 } & Solution No. 1 & Solution No. 2 & Solution No. 3 \\
\hline $\mathrm{NiSO}_{4} \cdot 7 \mathrm{H}_{2} \mathrm{O}$ & 30 & 30 & 30 \\
\hline $\mathrm{NaH}_{2} \mathrm{PO}_{2}$ & 10 & 20 & 30 \\
\hline $\mathrm{CH}_{3} \mathrm{COONa}$ & 10 & 10 & 10 \\
\hline $\mathrm{T}-{ }^{0} \mathrm{C}$ & $80-90$ & $80-90$ & $80-90$ \\
\hline
\end{tabular}

The higher the concentration of sodium hypophosphite in solution, the slower the rate of deposition of nickel. The thickness of the coating obtained as a result of the study is given in Table- 4 and Fig.-3.

Table-4: Coating Thickness Obtained by Different Composition of Sodium Hypophosphite

\begin{tabular}{c|c|c|c|c|c|c}
\hline \multirow{2}{*}{ S. No. } & \multicolumn{2}{|c|}{ Solution No. 1 } & \multicolumn{2}{c|}{ Solution No. 2 } & \multicolumn{2}{c}{ Solution No. 3 } \\
\cline { 2 - 7 } & $\Delta \mathrm{m}, \mathrm{g}$ & $\delta, \mathrm{mkm}$ & $\Delta \mathrm{m}, \mathrm{g}$ & $\delta, \mathrm{mkm}$ & $\Delta \mathrm{m}, \mathrm{g}$ & $\delta, \mathrm{mkm}$ \\
\hline 1 & 0.130 & 8.3 & 0.136 & 8.72 & 0.140 & 8.9 \\
\hline 2 & 0.120 & 7.7 & 0.111 & 7.0 & 0.115 & 7.38 \\
\hline 3 & 0.10 & 6.42 & 0.105 & 6.74 & 0.107 & 6.86 \\
\hline 4 & 0.070 & 4.49 & 0.075 & 4.8 & 0.081 & 4.85 \\
\hline 5 & 0.020 & 1.28 & 0.021 & 1.34 & 0.022 & 1.41 \\
\hline
\end{tabular}

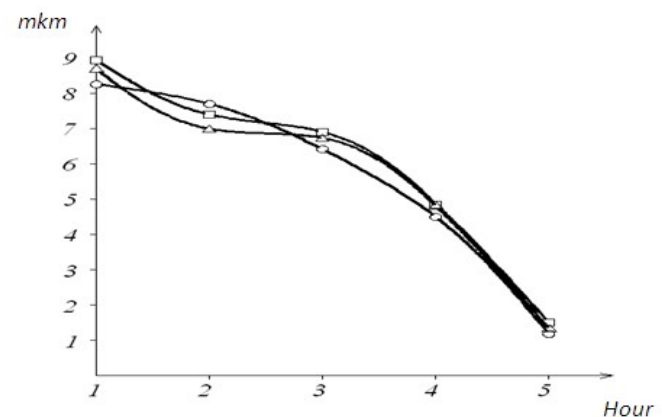

- Solution curve No.1; $\square$ - Solution curve No.2; $\triangle$ - Solution curve No. 3

Fig.-3: The Dependence of the Thickness of the Package on the Time Obtained From the Composition of Different Solutions

In this work, the influence on the appearance of nickel phosphide was investigated, in which the concentration of sodium acetate was taken as a surfactant. It is established that the higher the concentration of sodium acetate affects the appearance of the coating. When the composition of the solution was $10 \mathrm{~g} / \mathrm{L}$, a glossy, $20 \mathrm{~g} / \mathrm{L}$ strip, $30 \mathrm{~g} / \mathrm{L}$ brownish coating was obtained.

In this regard, the effect of ferrophosphorus powder on the appearance of the coating of nickel phosphide was studied in order to increase the corrosion resistance of the coating and the friction resistance. Table-5 shows the compositions of the solutions for which the studies were conducted. 
RASĀYAN J. Chem.

Vol. 13 | No. 1 |346 - 353| January - March | 2020

Table-5: The Content of Ferrophosphorus Powder in a Solution of Nickel Phosphide

\begin{tabular}{c|c|c|c|c|c}
\hline \multirow{2}{*}{ Components } & \multicolumn{5}{|c}{ The Concentration of Components in Solution, g / 1 } \\
\cline { 2 - 6 } & \multicolumn{5}{|c}{$5-6$} \\
\hline $\mathrm{NiSO}_{4} \cdot 7 \mathrm{H}_{2} \mathrm{O}$ & 30 & 30 & 30 & 30 & 30 \\
\hline $\mathrm{NaH}_{2} \mathrm{PO}_{2}$ & 10 & 10 & 10 & 10 & 10 \\
\hline $\mathrm{CH}_{3} \mathrm{COONa}$ & 10 & 10 & 10 & 10 & 10 \\
\hline Ferrophosphorus & 0.5 & 1 & 2 & 3 & 4 \\
\hline $\mathrm{T}-{ }^{\circ} \mathrm{C}$ & $80-90$ & $80-90$ & $80-90$ & $80-90$ & $80-90$ \\
\hline
\end{tabular}

According to the results of the study, the appearance of the coating, obtained with a concentration of ferrophosphorus powder up to $2 \mathrm{~g} / \mathrm{L}$, is brilliant. With a further increase in the concentration, dark color of the package was observed. A visual control of the quality of the coating on the samples indicated in Figure 4 shows that ferrophosphorus has an influence on the appearance of the powder.

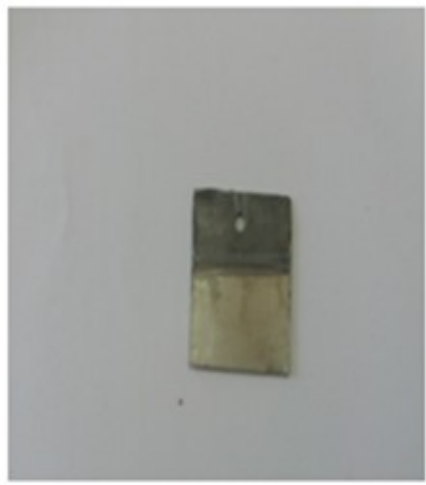

A

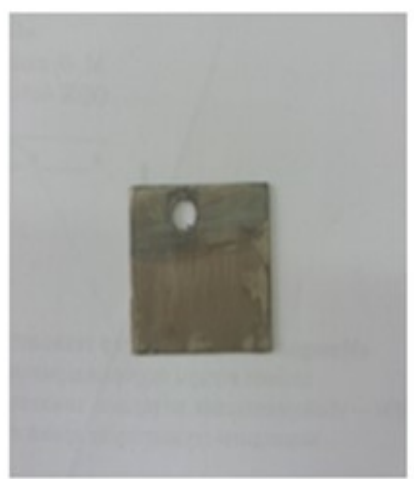

B

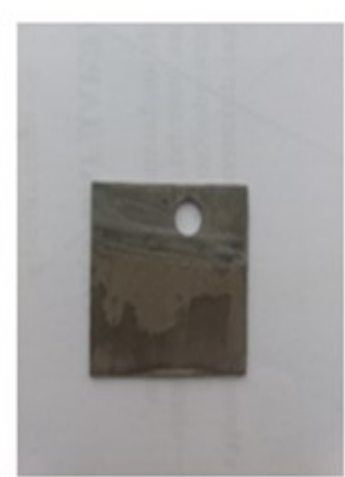

C

Fig.-4: Nickel-Phosphide Film with Ferrophosphorus Powder of Different Concentrations (A- Concentration of Ferrophosphorus Powder $2 \mathrm{~g} / \mathrm{L}$; B - Concentration of Ferrophosphorus Powder $3 \mathrm{~g} / \mathrm{L}$; C - Concentration of Ferrophosphorus Powder $4 \mathrm{~g} / \mathrm{L}$ )

The composition of the coatings obtained as a result of the study was later determined in the "Regional Laboratory of Constructional and Biochemical Materials" at the JSM-6490 LV (Japan) scanning electron microscope. Figure- 5 and Table- 6 show that the quality of the coating according to the results of studying the elemental composition of nickel phosphide obtained in a scanning electron microscope, meets the requirements.
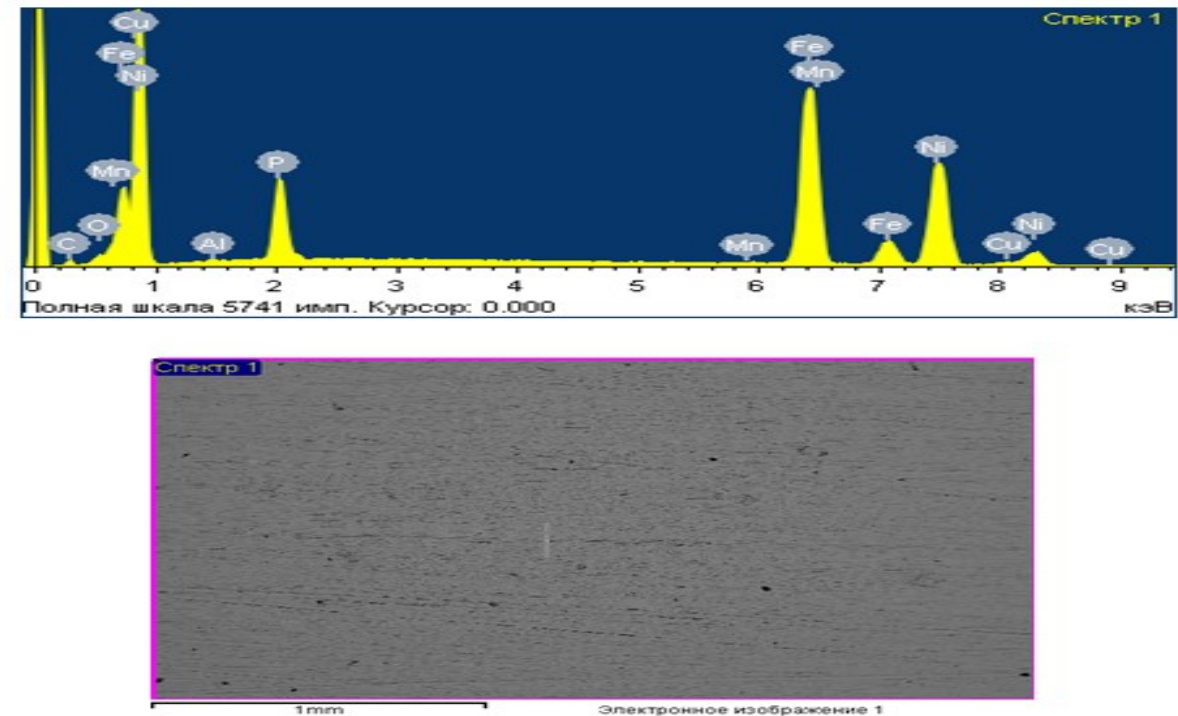

Fig.-5: Structural composition of nickel-phosphate film in which ferrophosphorus powder was added 
RASĀYAN J. Chem.

Vol. 13 | No. 1 |346 - 353| January - March | 2020

Table-6: Elemental Composition of Nickel-Phosphate Film in which Ferrophosphorus Powder was added

\begin{tabular}{c|c|c}
\hline Element & Weight, $\%$ & Atomic, $\%$ \\
\hline $\mathrm{C}$ & 0.31 & 4.31 \\
\hline $\mathrm{O}$ & 1.26 & 3.59 \\
\hline $\mathrm{Al}$ & 0.16 & 0.27 \\
\hline $\mathrm{P}$ & 7.43 & 10.90 \\
\hline $\mathrm{Mn}$ & 0.29 & 0.24 \\
\hline $\mathrm{Fe}$ & 43.84 & 35.69 \\
\hline $\mathrm{Ni}$ & 45.32 & 54.00 \\
\hline $\mathrm{Cu}$ & 1.39 & 1.00 \\
\hline
\end{tabular}

The appearance of the coating obtained in the composition of the solution with the addition of carborundum powder and mixing with air at a concentration of $1 \mathrm{~g} / 1$ is shown in Fig.-6.

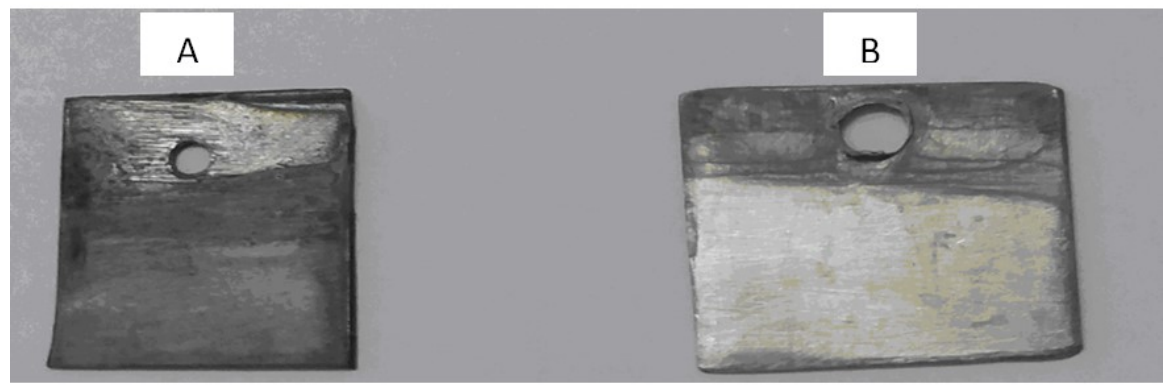

Fig.-6: Nickel-Phosphide Film Obtained with the Addition of Carborundum Powder by Magnetic Mixer (A) and Air Mixing (B)

When visually monitoring the quality of the coating obtained, obtained by blowing air, the highest and smooth coating. In addition, Tables-7 \& 8 and Figures-7 \& 8 show the elemental composition of the nickel phosphide coating obtained by magnetic mixer and air mixing with carborundum powder.

Table-7: Elemental Composition of the Nickel Phosphide Coating Obtained by Magnetic Mixer with Carborundum Powder

\begin{tabular}{c|c|c}
\hline Element & Weight, \% & Atomic, \% \\
\hline $\mathrm{C}$ & 16.72 & 35.06 \\
\hline $\mathrm{O}$ & 16.70 & 26.29 \\
\hline $\mathrm{Al}$ & 0.16 & 0.15 \\
\hline $\mathrm{Si}$ & 7.96 & 8,64 \\
\hline $\mathrm{P}$ & 9.33 & 7.58 \\
\hline $\mathrm{Fe}$ & 17.35 & 8.71 \\
\hline $\mathrm{Ni}$ & 31.78 & 13.56 \\
\hline
\end{tabular}

Table-8: Elemental Composition of the Nickel Phosphide Coating Obtained by Air Mixing with Carborundum Powder

\begin{tabular}{c|c|c}
\hline Element & Weight, $\%$ & Atomic, $\%$ \\
\hline $\mathrm{C}$ & 4.87 & 18.33 \\
\hline $\mathrm{O}$ & 1.12 & 3.18 \\
\hline $\mathrm{Si}$ & 0.38 & 0.61 \\
\hline $\mathrm{P}$ & 8.18 & 11.94 \\
\hline $\mathrm{Fe}$ & 3.83 & 3.10 \\
\hline $\mathrm{Ni}$ & 81.62 & 62.85 \\
\hline
\end{tabular}

As a result of research in the analysis of the quality and composition of the coatings found that the quality of coatings obtained by blowing is higher than using a magnetic stirrer. 
RASĀYAN J. Chem.

Vol. 13 | No. 1 |346 - 353| January - March | 2020
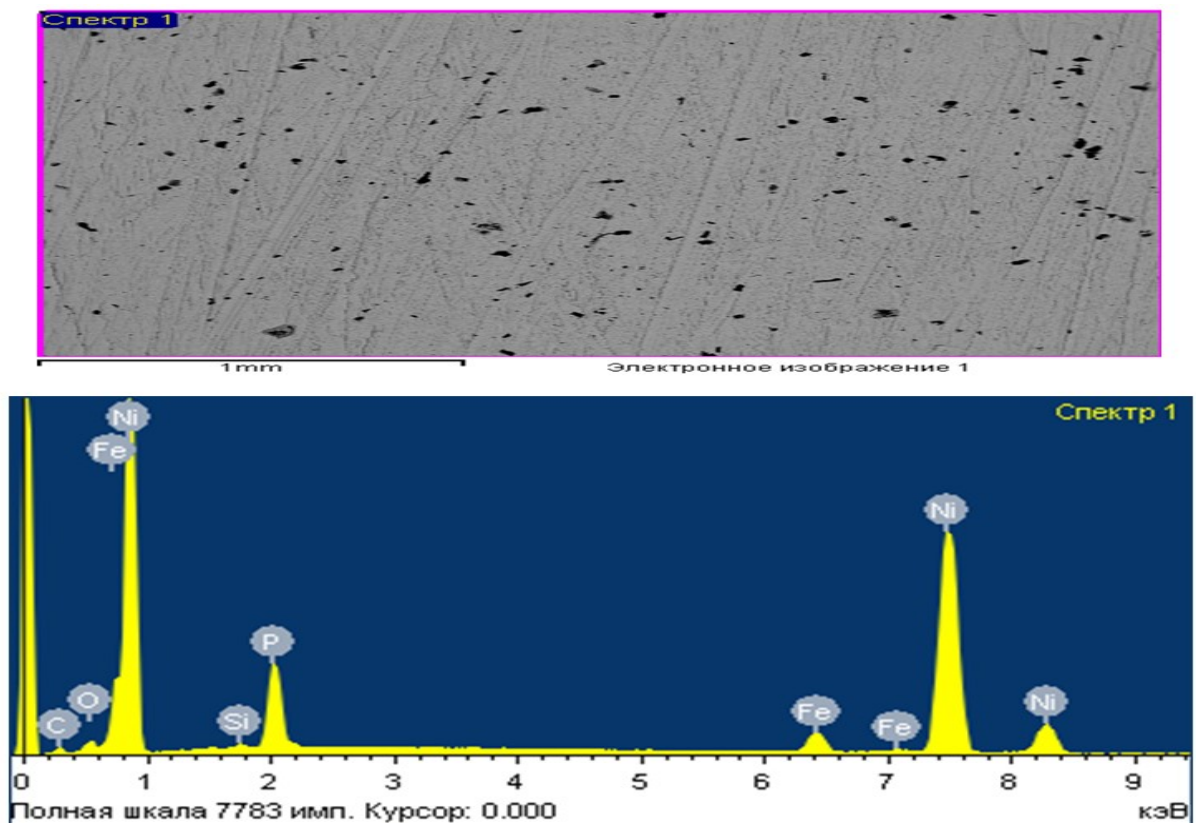

Fig.-7: Structural Composition of the Nickel Phosphide Coating Obtained by Magnetic Mixer with Carborundum Powder
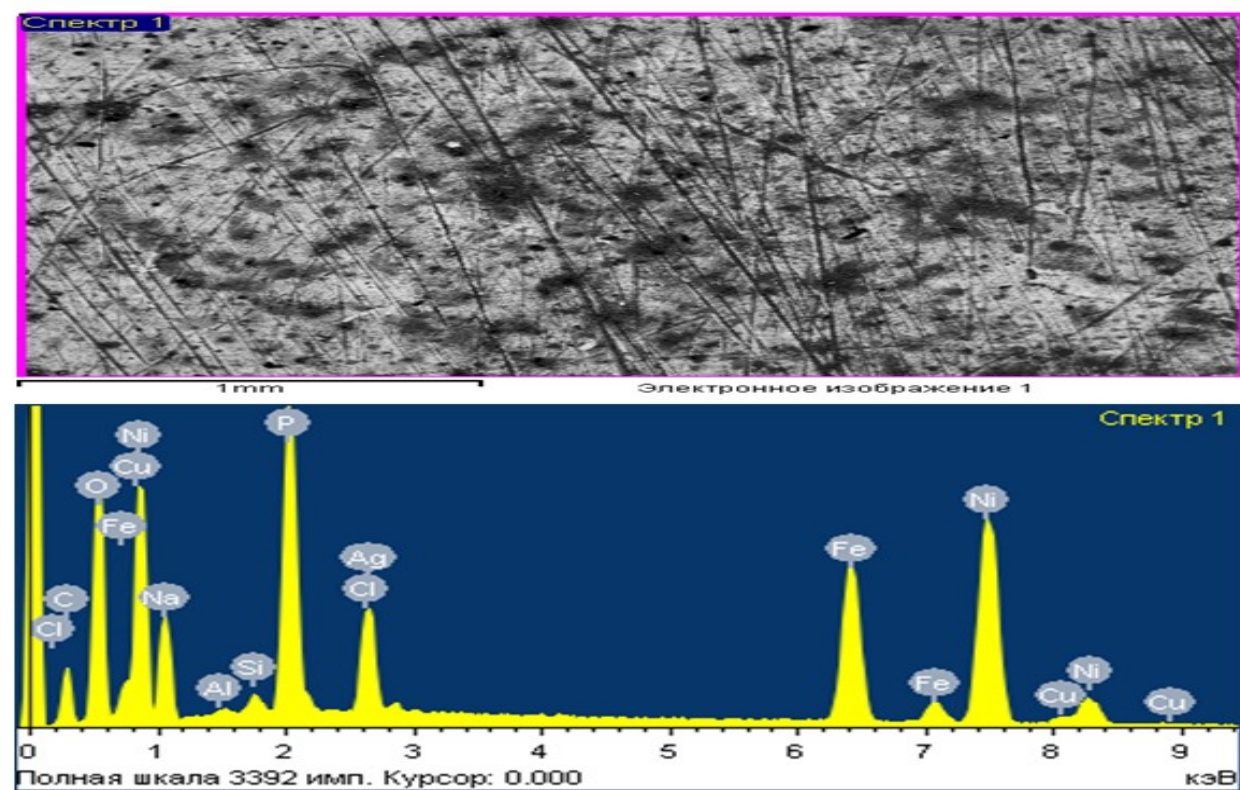

Fig.-8: Structural Composition of the Nickel Phosphide Coating Obtained by Air Mixing with Carborundum Powder

\section{CONCLUSION}

Studies have been carried out by adding several impurities to the work to obtain a coating of chemical nickel phosphide. All the coatings obtained are of good quality, but in the course of production, research has been carried out on ways to incorporate the coating in order to reuse the powder of ferrophosphorus, produced as an additional product. According to the results of the study, an analysis of the quality of the coating obtained was carried out, and the elemental composition was determined. The mass fractions of the elements $\mathrm{Al}, \mathrm{P}, \mathrm{Mn}, \mathrm{Fe}, \mathrm{Ni}$ in the composition of the obtained coating increase the corrosion resistance of the corresponding $0.16 ; 7.43 ; 0.29 ; 43.84 ; 45.32$, friction resistance. 
RASĀYAN J. Chem.

Vol. 13 | No. 1 |346 - 353| January - March | 2020

\section{REFERENCES}

1. M. S. Sataev, P. A. Abdurasova, Sh. T. Koshkarbaeva, A. A. Bolisbek, N. K. Saripbekova, G. A. Kambarova, O. N. Koblanova, S. Perni and P. Prokopovich, Colloids and Surfaces A: Physicochemical and Engineering Aspects, 521, 86(2017), DOI:10.1016/j.colsurfa.2016.11.029

2. P. A. Abdurazova, U. B. Nazarbek, A. A. Bolysbek, N. K. Sarypbekova, G. S. Kenzhibayeva, G. A. Kambarova, M. S. Sataev, Sh. T. Koshkarbaeva, A. B. Tleuova, S. Perni and P. Prokopovich, Colloids and Surfaces A: Physicochemical and Engineering Aspects, 532, 115(2017), DOI: 10.1016/j.colsurfa.2017.06.070

3. R. Kannan, M. Selvambikai, I. Jeena Rajathy and S. Anathi, Rasayan Journal of Chemistry, 10(4), 1213 (2017), DOI:10.7324/RJC.2017.1041925

4. Ashok Kumar, R.Shukla and A. Venkatachalam Rasayan Journal of Chemistry, 6(1), 12 (2013)

5. K. Elltaib, A. Benhmid and G. Mekhemer, Rasayan Journal of Chemistry, 8(3), 266 (2015)

6. M. S. Sataev, P. A. Abdurazova, Sh. T. Koshkarbaeva, A. B. Tleuova and A. P. Aueshov, Oriental Journal of Chemistry, 33(2), 835(2017), DOI:10.13005/ojc/330232

7. M. S. Sataev, Sh. T. Koshkarbaeva, P. A. Abdurazova, R. S. Abzhalov, U. B. Nazarbek and R. A. Issaeva, Oriental Journal of Chemistry, 34(6), 2755(2018), DOI:10.13005/ojc/340610

8. Sh. T. Koshkarbaeva, M. S.Sataev, P. A. Abdurazova, K. B. Amanbaeva and Ye. B. Raiymbekov, Bulletin of the University of Karaganda-Chemistry, 1(93), 85(2019), DOI:10.31489/2019Ch1/85-90

9. P. A. Abdurazova, Sh. T. Koshkarbayeva, M. S. Satayev, N. O. Dzhakipbekova and Ye. B. Raiymbekov, Bulletin of the University of Karaganda-Chemistry, 3(95), 45(2019), DOI: 10.31489/2019Ch3/45-51

[RJC-5539/209] 